Kampus 4 Universitas Ahmad Dahlan Jl. Ringroad Selatan, Tamanan, Banguntapan, Bantul

Daerah Istimewa Yogyakarta 55191

Telp. : (0274) 563515 Fax. : (0274) 564604

e-mail : ihtifaz@uad.ac.id

Vol.1, No 1\&2, Juni-Desember 2018, pp. 21-31

ISSN p:2622-4755 e:2622-4798.

DOI: https://doi.org/10.12928/ijiefb.v1i1.257

\title{
Issues of Sukuk Ijarah
}

\section{Faiza Husnayeni Nahar ${ }^{1 *}$, Mufti Alam Adha², Dyah Titis Kusuma Wardani ${ }^{3}$}

${ }^{1}$ Universitas Muhammadiyah Yogyakarta, Jl. Ringroad Selatan, Tamantirto,

Bantul, Daerah Istimewa Yogyakarta, Indonesia

'Universitas Ahmad Dahlan, Jl. Ringroad Selatan, Tamanan, Bantul, Daerah Istimewa Yogyakarta, Indonesia

${ }^{3}$ International Institute of Islamic Civilization \& Malay World (ISTAC), International Islamic University Malaysia

*e-mail: faizahusnayeni@umy.ac.id 
The current issue and full text archive of this journal is available on IHTIFAZ at :

https://doi.org/10.12928/ijiefb.v1i1.257

\title{
Issues of Sukuk Ijarah
}

\author{
Faiza Husnayeni Nahar ${ }^{1}$, Mufti Alam Adha ${ }^{2}$, \\ Dyah Titis Kusuma Wardani ${ }^{3}$ \\ ${ }^{1}$ Universitas Muhammadiyah Yogyakarta, Jl. Ringroad Selatan, Tamantirto, \\ Bantul, Daerah Istimewa Yogyakarta, Indonesia \\ 2 Universitas Ahmad Dahlan, Jl. Ringroad Selatan, Tamanan, Bantul, \\ Daerah Istimewa Yogyakarta, Indonesia \\ ${ }^{3}$ International Institute of Islamic Civilization \& Malay World (ISTAC), \\ International Islamic University Malaysia \\ *e-mail: faizahusnayeni@umy.ac.id
}

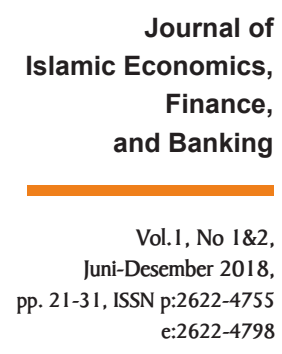

\begin{abstract}
Sukuk Ijarah is the most popular sukuk that increase in over the world since its start to introduce in 2001. Not only Muslim country who issued this sukuk, so do Non-Muslim Country such as Germany, Japan and China. However, there is issue that come up due to the non-existence of Shariah compliance in this structure such as the requirement of sukuk doesn't meet Maqasid Shari'ah perspective. Therefore, the aims of this paper to discuss some issue in sukuk Ijarah and give solution in order to develop Islamic capital market.
\end{abstract}

\section{Keywords:}

Sukuk Ijarah, Maqasid Shari'ah, Shariah Compliance, Islamic Capital Market

\begin{abstract}
Abstrak
Sukuk Ijarah adalah sukuk paling populer yang meningkat di seluruh dunia sejak mulai diperkenalkan pada tahun 2001. Bukan hanya negara Muslim yang mengeluarkan sukuk ini, begitu juga Negara Non-Muslim seperti Jerman, Jepang dan Cina. Namun, ada masalah yang muncul karena tidak adanya kepatuhan Syariah dalam struktur ini seperti persyaratan sukuk tidak memenuhi perspektif Maqasid Shari'ah. Oleh karena itu, tujuan makalah ini untuk membahas beberapa masalah di sukuk Ijarah dan memberikan solusi dalam rangka mengembangkan pasar modal syariah.
\end{abstract}

\section{Kata Kunci:}

Sukuk Ijarah, Maqasid Shari'ah, Kepatuhan Syariah, Pasar Modal Syariah

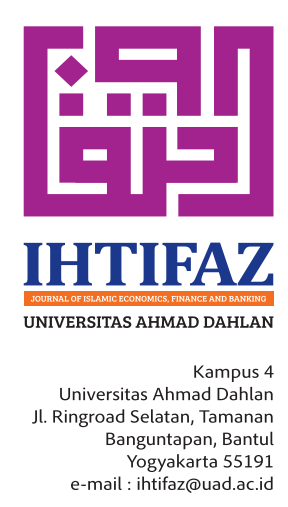




\section{INTRODUCTION}

Islamic capital market perform key role in investment activities, like IHTIFAZ - JIEFB securities transaction in debt and equity and supply financial resources (Ibrahim, 2006). Besides that, Islamic capital market plays important role to increase economic growth of country since this market facilitate people who want to do investment activity which is free from prohibited activity such as riba, gambling and ambiguity (Securities Comission Malaysia, 2009). One of component in Islamic capital market, called sukuk, is fastest growing segments in direct financial market (Chik, 2012). In the Malaysian Securities Commission's Guidelines on the Offering of Islamic Securities 2004, sukuk is security that issued based on Shariah principles and the concepts should accepted by Shariah Advisory Council (Securities Comission Malaysia, 2009). Afterwards sukuk guarantee access to a larger investor base, as well as provide potential lower pricing to issuers (Ascarya \& Yumanita, 2008).

One of many sukuk that most contribute to increase the economic welfare is sukuk Ijarah. Sukuk Ijarah is the most accepted sukuk among the Islamic scholars and the most popularly applied in the project financing (Yahya, Hussin, \& Muhammad, 2012)the role of Shariah Advisory Council (SAC. Accounting and Auditing Organization for Islamic Financial Institutions (AAOFI) defines sukuk Ijarah as sukuk that issued based on ijarah contract whereas one party (the owner or agent) sell the benefit of his asset to other party based on price and periodic lease rental agreement. In Malaysia, Sukuk Ijarah is one of the most popular sukuk structures in the global market since its first introduction in 2001. Likewise in Indonesia, although Islamic capital market just start to be developed in 2003, it gives confident improved to sukuk Ijarah with $72 \%$ in 2007 (Ascarya \& Yumanita, 2008). Not only Muslim country who developed sukuk especially sukuk Ijarah, but others country who realize that sukuk is becoming important to their country such as China, Japan, Thailand, Germany. Afterwards, the examples of sukuk Ijarah in over the world are Government of Bahrain Sukuk Ijarah, Segari Energy Venture Sukuk, Qatar Sukuk, Tabreed Global Ijara Sukuk, Pakistan Global Sukuk, Saxony-Anhalt Sukuk, Government of Malaysia's Global Sovereign Sukuk and others.

However, according to Al-Amine (2001) there is still challenging that come up due to the existing of Islamic capital market, especially sukuk which already diversified such as sukuk Ijarah and hybrid combination sukuk Ijarah with istisna and combination sukuk Ijarah with Istisna and Murabahah. It is needed to purify some instruments which are still debated. As well Syeikh Mufti Taqi Uthmani has critized on the sukuk Ijarah and concluded that almost all sukuk in the market are not in line with Shari'ah guidelines (Aziz \& Shahid, 2013).

Hence, this paper would like to stress the issue since sukuk Ijarah give big contribution to the country's economic. The remainder of the 
paper is organized as follows, section II discuss a review of the literature. Section III highlights the problem, challenges and opportunity. Section IV discusses the finding and the conclusion of the paper.

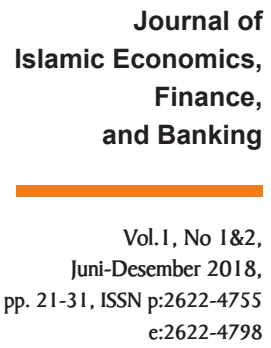

Sukuk is financial certificate. In the context of Islamic capital market refers to a process of securitizing. Security Commision explains sukuk as a financial document in which its value is based on property (Yahya et al., 2012)the role of Shariah Advisory Council (SAC. Actually sukuk can be used for an alternative financing which not only for countries (e.g. Malaysian Global Sovereign Sukuk) who can issue sovereign international sukuk, but those for regional governments (e.g. Sharjah) and corporation (e.g. Bank of Tokyo Mistubishi UFJ) that can issue sovereign and corporate sukuk to finance their project and expansion to capture Islamic wealth looking for Islamic investment (Ascarya \& Yumanita, 2008)According to Chik (2012), the benefit of sukuk are larger funding amounts and provide liquiity to the investors as they can trade it in the secondary market while Ascarya and Yumanita (2008) said that sukuk can be alternative source of long term and riba free financing, sukuk can be cheaper as a source of financing, sukuk provide mechanism for financing through mobilization of Islamic dormant asste and the important thing is sukuk has a wide array of Islamic concept to cater different needs of financing.

Ijarah is a contract between two parties or more which one party (lessor/the owner of assets or through agent) lease out the asset to the client at agreed lease price and duration of lease. The ownership of the asset remains with the lessor. This contract is totally different with the scheme of debtor-creditor since it is based on buyer-seller of an asset (Al-Amine, 2001). Then Securities Comission Malaysia (2009) explains that the issuer who needs financing will sell the asset to the client. Afterwards the same asset is leased back to the issuer for a lease rental. The duration of rental is becoming the periodic distribution to the client. The issuer will then issue the Islamic securities, called sukuk Ijarah to the client who are also lessor. Even though sukuk Ijarah has been popularly applied by government and private sector in ensuring the continuation of economic growth, sukuk Ijarah are limited use liquidity management instrument, at least until a large supply with periodic issuance becomes the norm an a secondary market in them develops. Besides that, initial structuring and issuance cost of sukuk Ijarah at the moments is quite high. Only large, credible and more transparent institution are so far able to participate in sukuk Ijarah deals (Ali, 2008). 


\section{Characteristic of Sukuk Ijarah}

According to Al-Amine (2001). there are four characteristics of IHTIFAZ - JIEFB sukuk Ijarah namely first sukuk Ijarah are securities representing the ownership of well-defined existing and well known assets, that are tied up to a lease contract. It means that sukuk Ijarah can be traded in the market at a price determined by market forces. Second is the expected net return on some form of sukuk Ijarah may not be completely fixed and determined in advance, since there might be some maintenance and insurance expenses that are ot perfectly determined in advance. Third is sukuk Ijarah are completely negotiable and can be traded in the secondary market. This sukuk will offer a high degree of liquidity and therefore, have both the characteristic and necessary conditions for functioning as successful securities. The last is sukuk Ijarah will offer a high degree of flexibility from the point of view of their issuance management and marketability.

Even though sukuk Ijarah has been popularly applied by government and private sector in ensuring the continuation of economic growth, sukuk Ijarah are limited use liquidity management instrument, at least until a large supply with periodic issuance becomes the norm an a secondary market in them develops. Besides that, initial structuring and issuance cost of sukuk Ijarah at the moments is quite high. Only large, credible and more transparent institution are so far able to participate in sukuk Ijarah deals (Ali, 2008).

\section{Scheme of Sukuk IJARAH}

Every each issuer in each country have different ways to show the sukuk Ijarah mechanism, but the main point of sukuk Ijarah remain the same. Hence the author explains the basic transaction structure of sukuk Ijarah that was applied in Segari Energy Ventures. In the structure (figure 1), Segari Energy Ventur Sdn Bhd (SEV) as issuer must have taken a particular "asset" from the investor on lease (ijarah). Normally, there asset is originally that of the issuer, and sold to investor (normally intermediated by a Special Purpose Vehicle (SPV), before being leased back to the issuer for rental. Hence, this lease contract has created a financial indebtedness to pay the lease rental (Chik, 2012). Actually the trading of sukuk Ijarah on the secondary market is not a trading of debt because they are backed by ownership of real tangible asset and not pure indebtedness in the form of monetary receivables (Securities Comission Malaysia, 2009). 
Figure 1. Basic Transaction Structure

\section{Segari Energy Ventures Sdn Bhd (SEV) Sukuk ljarah}

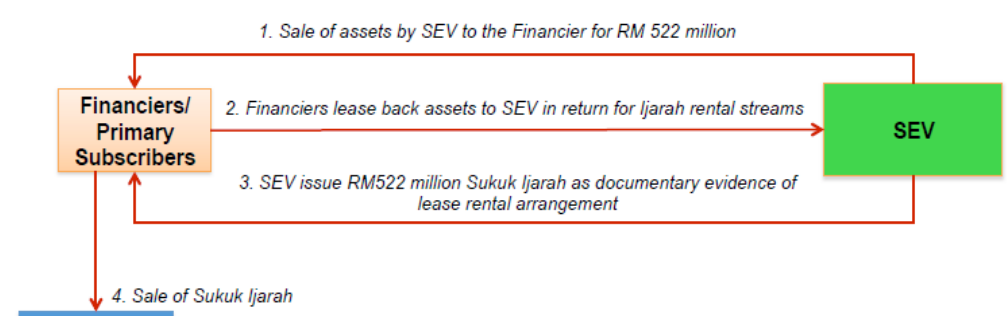

\section{Amãna Bank}

Source: (Chik, 2012)

\section{Development of Sukuk Ijarah}

Sukuk market has emerged from 2001 which start from Bahrain who issue domestic sovereign fixed rate sukuk Ijarah. It's followed by Malaysia's Globak sukuk was launched sukuk in 2002 which this sukuk was backed by an ijarah lease on a single piece of government property. Afterwards in 2004 a $€ 100$ million sukuk Ijarah was issued in the federal state of Saxony-anhalt whose debt is guaranteed by the Federal Republic of Germany and in the same year Dubai Civil Aviation Authority Sukuk also issued $\$ 1$ billion ijarah asset based sukuk (Brugnoni, 2008). Hence, author present brief description of some sukuk Ijarah issuance.

Table 1. Most Popular Sukuk Issues

\begin{tabular}{|c|c|c|c|c|}
\hline Name of Sukuk Ijarah & Type & Amount & $\begin{array}{l}\text { Matu- } \\
\text { rity }\end{array}$ & Pricing \\
\hline Malaysian Global First & $\begin{array}{l}\text { Guth- } \\
\text { rie Co., } \\
\text { (Planta- } \\
\text { tion Com- } \\
\text { pany) }\end{array}$ & US $\$ 150 M$ & 5 years & $\begin{array}{l}\text { Floating refer- } \\
\text { ence rate on } \\
\text { underlying } \\
\text { Ijarah }\end{array}$ \\
\hline $\begin{array}{l}\text { Malaysian Global Su- } \\
\text { kuk Ijarah }\end{array}$ & Sovereign & $\begin{array}{l}\text { US } \$ 500 \\
M\end{array}$ & 7 years & $\begin{array}{l}\text { Floating refer- } \\
\text { ence rate on } \\
\text { underlying } \\
\text { Ijarah }\end{array}$ \\
\hline $\begin{array}{l}\text { Qatar Global Sukuk } \\
\text { Ijarah }\end{array}$ & Sovereign & $\begin{array}{l}\text { US } \$ 700 \\
M\end{array}$ & 7 years & $\begin{array}{l}\text { Floating refer- } \\
\text { ence rate on } \\
\text { underlying } \\
\text { Ijarah }\end{array}$ \\
\hline $\begin{array}{l}\text { Tabreed Global Sukuk } \\
\text { Ijarah }\end{array}$ & Corporate & US \$150M & 5 years & $\begin{array}{l}\text { Floating refer- } \\
\text { ence rate on } \\
\text { underlying } \\
\text { Ijarah }\end{array}$ \\
\hline $\begin{array}{l}\text { Sukuk Ijarah Saxony- } \\
\text { Anhalt Germany }\end{array}$ & Sovereign & $\begin{array}{l}\text { Euro } € 100 \\
M\end{array}$ & 5 years & $\begin{array}{l}\text { Floating refer- } \\
\text { ence rate on } \\
\text { underlying } \\
\text { Ijarah }\end{array}$ \\
\hline
\end{tabular}


Dubai Department of

Civil Aviation (DCA)

Sukuk Ijarah

Floating refer-

Corporate US $\$ 750 \mathrm{M} \quad 5$ years

ence rate on

underlying

Ijarah

Source: (Tariq, 2004)

\section{The Shariah Principle Requirement}

According to Chik (2012) in order to make sukuk Ijarah is free from prohibited element; the lease payment should consist of lease profit and redemption amount on the capital. Then sukuk Ijarah doesn't represent debt but undivided proportionate ownership of the leased asset. The last is no increasing in issues of sale of monetary debts with discount since sukuk Ijarah are not debt. In addition Al-Amine (2001) said that the basic requirement of shariah compliance for sukuk structure is that it shall be backed by tangible assets. Hence sukuk Ijarah can trade freely in the secondary market.

\section{ISSUES IN SUKUK IJARAH: REVIEW OF LITERATURE}

Even though many people try to make a new instrument that applied Shariah compliance, it cannot be deny that there is a still person who make new instrument that use Shariah approach but still consist of riba, gharar and maysir. The irresponsible people just want to hide riba by term Shariah. As Al-Amine (2001) said that there is criticism addressed against this structure such as (i) the issue guarantee and whether its transform the transaction into a form of riba al duyun or not, (ii) the mechanism of sale and lease back and whether it consist of bay al-wafa or bay al-inah, (iii) the purchase undertaking at a predetermined price representing the original or principal amount if sukuk and (iv) the pricing mechanism of sukuk issuance which is generally tied to London InterBank Offer Rate (LIBOR) and not to the actual rental of the asset underlying the sukuk issue. Aziz and Shahid (2013) also said that sukuk Ijarah need to be evaluated on the scale of Maqasid al-shariah especially in the form of Maslahah and Mafsadah, element of hardship elimination in the structure, sad al-Zarai' or blocking the means to prohibited element in the structure and how far hiyah or legal trick being used in the structure of the sukuk. Thus, the following are criticism disscussion in detail against ijarah structure.

\section{Guarantee in Sukuk}

Al-Amine (2001) was realize that issue was come up since the originator benefiting from sukuk proceed establishes a Special Purpose 
they can't comment for these things since they have interest matters in this sukuk. Actually the guaranteed fund is used to purchase the sukuk of IDB and if this sukuk does not establish, the fund will not collected, not have been marketed and IDB will not developed until now.

\section{Sale and Lease Back Structure}

Second issue is about sale and lease back structure. There is scholar who said that sukuk Ijarah is the modified of Bay al-wafa or Bay alIstiglal or Bay al-Inah which those types of Bay was tested by majority Muslim scholars (Al-Amine, 2001). Bay al-Wafa is a contract whereas the owner of property sell its assets with the condition that he will take it back once he can repay the payment to the buyer. Simply said that the owner of asset just need money but he do not want lost their asset. In this case the buyer just helps the seller. Bay al-wafa is allowed on minority scholar and rejected in mayority scholar. So by renting the asset to whom can sell it cash give same result as such renting by ijarah Muntahiya $\mathrm{Bi}$ al-Tamleek (lease contract that ends with ownership). Hence these contracts have similarities characteristic. Likewise to Bay al-Istiglal that selling the assets with promise conditions whereas the seller lease out this asset, once he can pays back the price, he will get his asset and this is the end of sale and lease back contract. So does Bay al-Inah which consist of two sales in one transaction with spot price and others with the deferred higher price. This transaction like the seller needs the remaining money from this transaction (seller sell the asset to buyer and seller buys back by cash in lower price).

Thus, from the similarities between sukuk Ijarah and three types of bay is considered as trick of riba. Even AAOFI get trap for this structure since this corporate already approved this concept.

\section{Pricing of Sukuk}

Muslim economist and shariah scholar have not come up with an alternative to the interest rate as an indicator of profitability. Hence, LIBOR as a benchmark become part of practice in IFI. However even it is permissible to use LIBOR as benchmark it doesn't correct to rely on it for return determination. In sukuk Ijarah, sukuk holder is supposed to receive their return from the rent of the underlying asset of sukuk. However, in practise this return is not at all reflecting the rental of the underlying asset but the prevalent interest rate.

Muslim economists and shariah scholar have not found the alternative to delete interest rate as profitability indicator. Hence, LIBOR is used as benchmark for practice in Islamic Financial Institution. However, 
even it is permissible to use LIBOR as benchmark, it does not correct to depend on it for return determination. In sukuk Ijarah, sukuk holder receives their return from the rent of underlying asset of sukuk. However, practically, this return is not mostly reflecting the rental but it was interest rate. For example there are two real asset which totally different from each other. Then it is expected to get different return based on market realities. Unfortunately, it is observed that same rate of return as reflecting at the common interest rate, so they will get same return if they are used underlying asset for two different sukuk issues. This kind of practise is not justice even unacceptable from shariah perspective; beside that it also give commercial impact. Thus, the sukuk return is not reflecting the underlying asset performance but the prevalent interest rate. Given the discourse so far, it is clearly to say that the price of sukuk exactly same as the conventional bond.

\section{Sukuk Ijarah in Scale of Maqasid Shariah}

\section{Brief definition of Maqasid Shariah}

Maqasid al-Shari'ah is the objectives, spirit and the rational of the Shari'ah. The objective is to secure the interest for human being and prevent them from the harm. Besides that there are five ultimate purposes of the law, namely religion, life, progeny, intellect and wealth. These five purposes are designated as dharuriyyat (necessities) and are the primary purposes of the law. These are followed by the hajiyat (needs), which are additional purposes required by the primary purposes, even though the primary purposes would not be lost without them. The third category is that of purposes that seek to establish ease and facility in the law, these are called the tahsiniyyat (complementary values).

\section{Maqasid Shari'ah in Sukuk Ijarah}

According to Aziz and Shahid (2013), sukuk Ijarah needs to be evaluated on the scale of Maqasid al-Shariah. There are four problems that come up from this sukuk, namely. First, in the form of maslahah and mafsadah, second is the harm avoidance in the structure. Third is Sad al-Zara'i or blocking the means to prohibited element in the structure and last is how far hiyal or legal trick being used in sukuk structure.

The first issue need to be analysed through the light of Maqasid Shariah is sukuk securitization. Is it securitization appropriate with the Maqasid Shariah principle? Is it maslahah for issuer of sukuk since the issuer need the fund? Or is it the maslahah not represent a forbidden hilah that scholar clearly prohibit it in financial transaction? The concept 
of Sad al-Zara'i also need to be reflected in this issue where it provide the precaution for the parties in sukuk to protect their rights and wealth.

Even though Special Purpose Vehicle/Company (SPV) is imitation of conventional lease concept, but SPV has good purposes, one of them is to fulfil the duty from sukuk issuer to sukuk holder by good management. However, Maqasid Shariah concern about the establishment of SPV which spend high cost. Aziz and Shahid (2013) said that SPV will reduce the cost regarding the issuance of sukuk whereas the issuer can get high return. Hence, by this discussion perhaps the understanding of application of Maqasid Shariah to SPV as one variable in sukuk Ijarah is increase.

Originally, SPV is chosen as representative of sukuk owner in order to undertake market activity on its behalf. Actually, the concept of SPV applied wakalah concept beside promotes transparency and leniency in financial transaction that relate to issue sukuk. However, the cost of establishment SPV still need to be discusses since it is trigger the Maqasid Shariah perspective to determine whether it is SPV really needed in the transaction in order to protect the wealth? Or removing the agent in order to gain the profit of investor and issuer?

Other things that should be examined in the light of Maqasid Shari'ah are the price and listing sukuk. Like previous issue in pricing of sukuk, sukuk follow the price mechanism that determined by LIBOR. The measurement of price sukuk comes from time, maturity and currency rates. This practice should be check based on Maqasid Shariah principle especially the issue of choose LIBOR as benchmark for sukuk pricing. In case, if LIBOR was removed from the capital market activity, what is the need of sukuk to the rate whether use daruriyyat, hajiyyat or tahsiniyat.

Afterwards, there is important thing that would effect sukuk namely law. Law is very important to create the credibility of sukuk issuer and protect the rights of sukuk holder. Thus, it is necessary to establish law based on Shariah Perspective. Unfortunately, the laws mostly come from British or common law which do not concern on Shariah area. Is it Non Shariah law can give a justice to solve in the case of Islamic financial activity? How Maqasid Shariah solve sukuk problem?

To sum up, all of elements that involved in sukuk Ijarah definitely already proceed based on Maqasid Shariah perspective whereas the sukuk application fulfilled by spirit of Islamic law. By fulfil all requirement of Maqasid Shariah, then it recognize as shariah product.

\section{CONCLUSION}

Sukuk Ijarah issue has been discuseed well, and then it is become our responsible as Islamic Economic student to develop sukuk ijarah as sukuk that (really) applied Shariah compliance. If we cannot make a new alternative instrument for nowadays, at least we share the knowl- 
edge and we spread the spirit of Islamization of economy because Allah would see our effort. Muslim scholar, Islamic economist, Government should make good cooperation. So it is not only how to rise fund and acceptable to International financial institution. The important things are every financial activity should consist of Maqasid Shari'ah and ouf course the Shariah compliance. Besides that, the standardised contrast need to be identified that can be approved by Islamic Infrastructure Institution such as AAOFI, IFSB (Islamic Financial Service Board) and IIFM (International Islamic Financial Market). In addition, author suggests more detail on analysis of issues to further research.

\section{REFERENCES}

Al-Amine, M. al-B. M. (2001). The Islamic Bonds Market: Possibilities and Challenges. International Journal of Islamic Financial Services, 3 (1), 1--18.

Ali, S. S. (2008). Islamic Capital Markets Products, Regulations and Development. Islamic Economic Studies (Vol. 15).

Ascarya, \& Yumanita, D. (2008). Comparing The Development of Islamic Financial / Bond Markets in Malaysia and Indonesia. Islamic Capital Markets: Products, Regulation and Development.

Aziz, M. R. A., \& Shahid, M. F. I. (2013). The Structure of Sukuk Ijarah: An Initial Analysis From The Perspective of Maqasid Al-Shariah. Paper Proceeding of the 5th Islamic Economics System Conference (iECONS 2013), "Sustainable, (September), 4-5.

Brugnoni, A. (2008). Shariah Governance at Work : from Asset-Based to Asset-Backed Sukuk. SHIRKAH, (7), 1-26.

Chik, M. N. (2012). Sukuk : Shariah Guidelines for Islamic Bonds. Centre for Banking Studies, Central bank of Sri Lanka.

Ibrahim, A. A. (2006). Developing Governance and Regulation for Emerging Capital an

Securities Markets. Washington DC: the Georgetown Law Library.

Securities Comission Malaysia. (2009). The Islamic Securities (Sukuk) Market. Malaysia:LexisNexis Malaysia Sdn Bhd.

Tariq, A. A. (2004). Managing Financial Risks of Sukuk Structures. Loughborough University, UK.

Yahya, M., Hussin, M., \& Muhammad, F. (2012). Development of Sukuk Ijarah in Malaysia. Journal of Islamic Economics, Banking and Finance, 8 (2), 92-101.

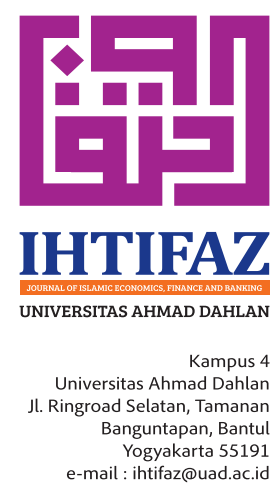

